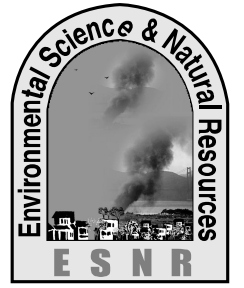

J. Environ. Sci. \& Natural Resources, 4(2): 19-26, 2011

ISSN 1999-7361

\title{
Effects of Tillage and Different Thicknesses of Water Hyacinth Mulch on the Growth and Yield of Garlic
}

\author{
M. A. Kabir ${ }^{1}$, M. A. Rahim ${ }^{2}$, H. F. El. Taj ${ }^{3}$, D. A. N. Majumder ${ }^{4}$ and Shreef Mahmood ${ }^{1}$ \\ ${ }^{1}$ Department of Horticulture, Hajee Mohammad Danesh Science and Technology University, Dinajpur \\ ${ }^{2}$ Department of Horticulture, Bangladesh Agricultural University, Mymensingh \\ ${ }^{3}$ Department of Entomology, Hajee Mohammad Danesh Science and Technology University \\ ${ }^{4}$ Plant Biotechnology Lab, BRAC Agricultural Research and Development Centre
}

\begin{abstract}
Different growth parameters of garlic as well as bulb yield were found significant in respect of the treatments. Nonetheless, the combination of $10 \mathrm{~cm}$ thick mulch with zero tillage produced the highest yield $(9.92 \mathrm{t} / \mathrm{ha})$. On the contrary, the lowest yield (4.23 $\mathrm{t} / \mathrm{ha}$ ) was obtained from no mulch with zero tillage. Economic analysis among the treatment combinations showed that the total cost of production was the highest in $12 \mathrm{~cm}$ thick mulch with conventional tillage, however, the highest BCR (2.89) was recorded from the zero tillage with $10 \mathrm{~cm}$ mulch.
\end{abstract}

Key words: Tillage, Mulch thickness, Garlic, Yield

\section{Introduction}

Garlic (Allium sativum L) is an annual crop and popular all over the world as a valuable spice for different dishes. It is the second most widely used Allium after onion (Bose and Som, 1990) with a characteristic of pungent smell. The aqueous extract of garlic cloves (containing allicin and related disulphides) reduces cholesterol level in humans (Augusti, 1977). Garlic also helps eliminating waste materials and dangerous free radicals from the human body. The production of garlic bulb is greatly influenced by organic manure, tillage and mulch (Baten et al., 1995). Out of these, tillage practices play a vital role in conserving soil moisture at different depths of the soil profile. As garlic is grown during the dry spell, farmers have to depend either on natural precipitation or on irrigation (Baten et al., 1995). Oppositely, irrigation facilities are insufficient in all the regions of Bangladesh. Therefore, mulching may be an effective cultural practice to ensure crop production, especially in the dry season. In wet land farming, growth of garlic may be hampered by weed if mulch materials are not used properly. So, in the present experiment, the effects of tillage and different thicknesses of mulches on the growth and yield of garlic were studied.

\section{Materials and Methods}

An experiment was conducted at the field laboratory, USDA-Alliums' project, Bangladesh Agricultural University, Mymensingh during rabi seasons of 20062007. The experiment was conducted at the Horticulture Farm, Bangladesh Agricultural University, Mymensingh under the Agro-ecological zone of Old Brahmaputra floodplain. The experiment was consisted of five depths of water hyacinth mulch $(0,6,8,10$ and $12 \mathrm{~cm})$ and two methods of tillage (conventional and zero). It was laid out in the Randomized Complete Block Design (RCBD) with three replications. In the conventional tillage, a good tilth of soil was made by four ploughings followed by laddering. On the other hand, in the zero tillage conditions the plot was arranged without any tillage practices. The initial soil moistures of the lands were 30.26 and $71.42 \%$, respectively. Moreover, soil moisture content after fifteen days of planting was estimated due to the variation of different thicknesses of water hyacinth mulch. Cow dung @ 20 t/ha was applied as the basal dose. In case of conventional tillage conditions, cow dung was applied in the plot and mixed well with the soil by spading. But under zero tillage conditions, it was applied on the soil. The cloves of garlic were planted on 15 November, 2006. Immediately after planting $6,8,10$ and $12 \mathrm{~cm}$ thick dry water hyacinth mulch was added to the plots as per the treatments. The crop was always kept under careful observation and it was harvested on the $28^{\text {th }}$ march, 2007. The bulbs were cured for 4 days under shade before storing in an ordinary room (Pruthi, 2006).Ten plants were selected at random from each plot for the collection of data. The following data were recorded: Emergence of plant (\%), plant height $(\mathrm{cm})$, no. of leaves per plant, length of the longest leaf per plant $(\mathrm{cm})$, breadth of the longest leaf per plant $(\mathrm{cm})$, fresh weight of leaves per plant $(\mathrm{g})$, dry weight of leaves per plant $(\mathrm{g})$, fresh weight of roots per plant (g), dry weight of roots per plant $(\mathrm{g})$, fresh weight of bulbs per plant $(\mathrm{g})$, dry weight of bulbs per plant $(\mathrm{g})$, diameter of bulbs $(\mathrm{cm})$, no. of cloves per bulb, yield of bulb per plot $(\mathrm{kg})$ and yield of bulb per hectare $(\mathrm{t})$. The collected data were statistically analyzed and the mean differences were tested by the Least Significant Difference test (Gomez and Gomez, 1984). 


\section{Results}

Effect of different thicknesses of mulch on garlic

The results presented in the Table 1 shows that the effects due to variation among the thickness of mulch were significant regarding the percent of emergence of the plant. The highest emergence $(96.87 \%$ ) was obtained from the $6 \mathrm{~cm}$ thick mulch. The plants grown with $12 \mathrm{~cm}$ thickness of mulch gave the least emergence $(89.95 \%)$ per plot closely followed by the control $(91.25 \%)$. The tallest plants $(64.80 \mathrm{~cm})$ were obtained from the plots in $10 \mathrm{~cm}$ mulch at 90 DAP. The plant height increased with the advance of time from 30 to 90 days after planting and the shortest plant $(21.07 \mathrm{~cm})$ was found in plots without mulch $\left(\mathrm{D}_{0}\right)$ at 30 DAP (Table 1). Treatment means in terms of number of leaves per plant was significant at 30, 50, 70, 90 and 110 DAP (Table 1). On the contrary, the highest number of leaves per plant (6.85) was found from the $8 \mathrm{~cm}$ thick mulch at 90 DAP. Length and breadth of the longest leaf at 30, 50, 70, 90 and 120 days after planting differed significantly due to the thickness of mulch. The longest leaf $(42.93 \mathrm{~cm})$ was found from $8 \mathrm{~cm}$ thick mulch at 70 DAP and the shortest leaf $(17.70 \mathrm{~cm})$ was observed from without mulch at 30 DAP (Table 2). It was observed that breadth of the longest leaf gradually increased with the increasing trend of mulch upto $10 \mathrm{~cm}$ thick and then declined when the mulch was $12 \mathrm{~cm}$. The maximum breadth of the longest leaf $(1.40 \mathrm{~cm})$ was recorded at the 90 days after planting from the $10 \mathrm{~cm}$ thick mulch. Fresh weight of leaves per plant was affected significantly by the thickness of mulch. The maximum fresh weight of leaves $(9.77 \mathrm{~g})$ was obtained when the plants were grown in $10 \mathrm{~cm}$ thick mulch $\left(\mathrm{D}_{3}\right)$ which was closely followed by $\mathrm{D}_{2}(9.50 \mathrm{~g})$ and the $\mathrm{D}_{4}(8.70$ $\mathrm{g})$. The minimum fresh weight of leaves $(5.77 \mathrm{~g})$ was observed from without mulch (Table3). Again, the highest fresh weight of bulb (15.10 g) and roots per plant $(0.64 \mathrm{~g})$ were obtained from the $10 \mathrm{~cm}$ thick mulch $\left(D_{1}\right)$. The increased fresh weight of leaves, bulb and roots per plant at $10 \mathrm{~cm}$ thick mulch was probably due to optimum soil moisture into the soil. The maximum dry weight of leaves $(1.10 \mathrm{~g})$ and roots per plant $(0.22 \mathrm{~g})$ were obtained when the plants were grown with $8 \mathrm{~cm}$ thick mulch $\left(\mathrm{D}_{2}\right)$.

On the other hand, the highest dry weight of bulbs $(3.35 \mathrm{~g})$ was found at $10 \mathrm{~cm}$ thick mulch. Different thicknesses of mulch had significant influence on the diameter of bulb and no. of cloves per plant. The diameter of bulb was highest $(3.15 \mathrm{~cm})$ when the plants were grown with $10 \mathrm{~cm}$ thick mulch which was significantly different from the treatment without mulch. Once more, the highest number of cloves per bulb (13.13) was recorded from the $10 \mathrm{~cm}$ thick mulch. A highly significant variation in respect of yield per plot as well as hectare was observed among the different thicknesses of mulch. The highest yields per plot $(1.84 \mathrm{~kg})$ and hectare $(9.17 \mathrm{ton})$ were obtained from the treatment $\mathrm{D}_{3}$ and the lowest $(1.04 \mathrm{~kg} / \mathrm{plot}$ and 5.20 ton/ha) was in the control (Table 3).

Table 1. Main effects of different thicknesses of mulch on the growth and yield of garlic

\begin{tabular}{|c|c|c|c|c|c|c|c|c|c|c|c|}
\hline \multirow{2}{*}{ Treatment } & Emergenc & \multicolumn{4}{|c|}{$\begin{array}{c}\text { Plant height }(\mathrm{cm}) \\
\text { at different DAP } \\
\end{array}$} & \multicolumn{4}{|c|}{$\begin{array}{c}\text { Number of leaves/plant } \\
\text { at different DAP }\end{array}$} \\
\cline { 3 - 14 } & 30 & 50 & 70 & 90 & 110 & 30 & 50 & 70 & 90 & 110 \\
\hline $\mathrm{D}_{0}$ & 91.25 & 21.07 & 26.43 & 34.67 & 49.63 & 44.87 & 3.50 & 3.97 & 4.30 & 5.85 & 5.57 \\
\hline $\mathrm{D}_{1}$ & 96.87 & 27.73 & 32.60 & 50.20 & 60.63 & 58.27 & 4.47 & 4.67 & 5.13 & 6.42 & 6.23 \\
\hline $\mathrm{D}_{2}$ & 95.72 & 30.67 & 34.00 & 55.23 & 63.40 & 60.80 & 4.60 & 4.87 & 5.63 & 6.85 & 6.65 \\
\hline $\mathrm{D}_{3}$ & 95.58 & 32.23 & 34.37 & 53.27 & 64.80 & 63.33 & 4.83 & 5.13 & 5.77 & 6.63 & 6.43 \\
\hline $\mathrm{D}_{4}$ & 89.95 & 30.70 & 33.00 & 50.70 & 63.37 & 61.57 & 4.43 & 4.80 & 5.50 & 6.52 & 6.30 \\
\hline LSD 5\% & 2.48 & 2.01 & 2.71 & 3.80 & 4.71 & 4.67 & 0.31 & 0.27 & 0.47 & 0.54 & 0.50 \\
\hline LSD 1\% & 3.40 & 2.76 & 3.71 & 5.21 & 6.46 & 6.40 & 0.42 & 0.38 & 0.65 & 0.74 & 0.69 \\
\hline $\begin{array}{c}\text { Level of } \\
\text { significance }\end{array}$ & $* *$ & $* *$ & $* *$ & $* *$ & $* *$ & $* *$ & $* *$ & $* *$ & $* *$ & $* *$ & $* *$ \\
\hline
\end{tabular}

$\mathrm{D}_{0}=$ without mulch, $\mathrm{D}_{1}=6 \mathrm{~cm}, \mathrm{D}_{2}=8 \mathrm{~cm}, \mathrm{D}_{3}=10 \mathrm{~cm}, \mathrm{D}_{4}=12 \mathrm{~cm}$ thick mulch

** Significant at $1 \%$ level 
Table 2. Main effects of different thicknesses of mulch on the length and breadth of the longest leaf/plant of grlic

\begin{tabular}{|c|c|c|c|c|c|c|c|c|c|c|}
\hline \multirow{2}{*}{ Treatments } & \multicolumn{4}{|c|}{$\begin{array}{c}\text { Length of the longest leaf }(\mathrm{cm}) \\
\text { at different DAP }\end{array}$} & \multicolumn{4}{c|}{$\begin{array}{c}\text { Breadth of the longest leaf }(\mathrm{cm}) \\
\text { at different DAP }\end{array}$} \\
\cline { 2 - 14 } & 30 & 50 & 70 & 90 & 110 & 30 & 50 & 70 & 90 & 110 \\
\hline $\mathrm{D}_{0}$ & 17.70 & 21.43 & 27.97 & 30.37 & 26.67 & 0.43 & 0.68 & 1.03 & 0.10 & 1.07 \\
\hline $\mathrm{D}_{1}$ & 22.10 & 26.23 & 37.60 & 36.07 & 34.83 & 0.51 & 0.79 & 1.18 & 1.28 & 1.24 \\
\hline $\mathrm{D}_{2}$ & 25.57 & 28.20 & 42.93 & 38.97 & 37.13 & 0.54 & 0.84 & 1.26 & 1.37 & 1.33 \\
\hline $\mathrm{D}_{3}$ & 27.27 & 28.30 & 41.73 & 41.00 & 37.43 & 0.57 & 0.85 & 1.28 & 1.40 & 1.34 \\
\hline $\mathrm{D}_{4}$ & 25.20 & 27.40 & 38.20 & 38.90 & 35.47 & 0.53 & 0.83 & 1.20 & 1.31 & 1.28 \\
\hline LSD 5\% & 2.57 & 2.56 & 3.14 & 2.77 & 2.02 & 0.04 & 0.07 & 0.05 & 0.14 & 0.06 \\
\hline LSD 1\% & 3.52 & 3.51 & 4.30 & 3.79 & 2.77 & 0.05 & 0.09 & 0.07 & 0.20 & 0.08 \\
\hline Level of significance & $* *$ & $* *$ & $* *$ & $* *$ & $* *$ & $* *$ & $* *$ & $* *$ & $* *$ & $* *$ \\
\hline
\end{tabular}

$\mathrm{D}_{0}=$ without mulch, $\mathrm{D}_{1}=6 \mathrm{~cm}, \mathrm{D}_{2}=8 \mathrm{~cm}, \mathrm{D}_{3}=10 \mathrm{~cm}, \mathrm{D}_{4}=12 \mathrm{~cm}$ thick mulch

** Significant at $1 \%$ level

Table 3. Main effects of different thicknesses of water hyacinth mulch on the yield and yield contributing characteristics of garlic

\begin{tabular}{|c|c|c|c|c|c|c|c|c|c|}
\hline \multirow{2}{*}{ Treatment } & \multicolumn{3}{|c|}{ Fresh weight (g) of } & \multicolumn{2}{c|}{ Dry weight (g) of } & $\begin{array}{c}\text { Bulb } \\
\text { diameter } \\
\text { (cm) }\end{array}$ & $\begin{array}{c}\text { Cloves } \\
\text { /bulb } \\
\text { (no.) }\end{array}$ & $\begin{array}{c}\text { yield } \\
\text { (kg/plot) }\end{array}$ \\
\hline $\mathrm{D}_{0}$ & 5.77 & 9.03 & 0.49 & 0.73 & 1.45 & 0.12 & 2.24 & 7.77 & 1.04 \\
\hline $\mathrm{D}_{1}$ & 7.70 & 12.17 & 0.57 & 0.95 & 2.49 & 0.18 & 2.85 & 10.73 & 1.45 \\
\hline $\mathrm{D}_{2}$ & 9.50 & 14.97 & 0.63 & 1.10 & 3.18 & 0.22 & 3.07 & 13.03 & 1.82 \\
\hline $\mathrm{D}_{3}$ & 9.77 & 15.10 & 0.64 & 1.08 & 3.35 & 0.21 & 3.07 & 13.13 & 1.84 \\
\hline $\mathrm{D}_{4}$ & 8.70 & 13.90 & 0.62 & 1.01 & 2.97 & 0.20 & 2.91 & 12.63 & 1.62 \\
\hline LSD 5\% & 1.14 & 1.63 & 0.09 & 0.12 & 0.21 & 0.02 & 0.17 & 1.73 & 0.16 \\
\hline LSD 1\% & 1.56 & 2.23 & 0.12 & 0.16 & 0.29 & 0.03 & 0.24 & 2.37 & 0.22 \\
\hline Level of significance & $* *$ & $* *$ & $* *$ & $* *$ & $* *$ & $* *$ & $* *$ & $* *$ & $* *$ \\
\hline
\end{tabular}

$\mathrm{D}_{0}=$ without mulch, $\mathrm{D}_{1}=6 \mathrm{~cm}, \mathrm{D}_{2}=8 \mathrm{~cm}, \mathrm{D}_{3}=10 \mathrm{~cm}$ and $\mathrm{D}_{4}=12 \mathrm{~cm}$ mulch

** Significant at $1 \%$ level

\section{Effect of tillage on garlic}

The variations due to different tillage conditions under the study were highly significant in respect of percent emerged plant per plot. The highest emerged plants $(94.82 \%)$ were recorded from the zero tillage conditions, whereas the lowest $(92.93 \%)$ was from the well tilth plot under dry land conditions (Table 4). It was observed that zero tillage produced the highest plant $(61.87 \mathrm{~cm})$ and maximum leaves per plant $(6.46)$ at 90 days after planting. On the other hand, the lowest plant height $(24.23 \mathrm{~cm})$ and the minimum number of leaves per plant (4.31) were found in conventional tillage system at 30 days after planting.

The variations due to different tillage conditions under the study were highly significant in respect of the length of the longest leaf per plant at different DAP. The length of the longest leaf per plant $(38.69 \mathrm{~cm})$ was recorded from the zero tillage conditions at 70 DAP and the lowest (20.31) was in the conventional tillage at 30 DAP (Table 5). Again, the highest breadth of the longest leaf per plant (1.30 $\mathrm{cm}$ ) was recorded from the zero tillage conditions at 90 DAP and the lowest $(0.47 \mathrm{~cm})$ was from the conventional tillage at 30 DAP. Non significant effects were observed on fresh and dry weight of leaves, bulb and roots per plant due to the main effects of tillage conditions. The results also revealed that there was a non significant difference between the conventional and zero tillage conditions in respect of diameter of bulb, no. of cloves per bulb, yield per plot as well as per hectare (Table 6). 
Table 4. Main effects of tillage on the growth of garlic

\begin{tabular}{|c|c|c|c|c|c|c|c|c|c|c|c|}
\hline Treatment & $\begin{array}{c}\text { Emergence } \\
(\%)\end{array}$ & \multicolumn{4}{|c|}{$\begin{array}{c}\text { Plant height }(\mathrm{cm}) \\
\text { at different DAP }\end{array}$} & \multicolumn{5}{c|}{$\begin{array}{c}\text { Number of leaves/plant } \\
\text { at different DAP }\end{array}$} \\
\cline { 3 - 15 } & & 30 & 50 & 70 & 90 & 110 & 30 & 50 & 70 & 90 & 110 \\
\hline $\mathrm{C}_{\mathrm{t}}$ & 92.93 & 24.23 & 31.11 & 45.84 & 58.87 & 55.49 & 4.47 & 4.53 & 5.25 & 6.46 & 6.19 \\
\hline $\mathrm{Z}_{\mathrm{t}}$ & 94.82 & 32.73 & 33.05 & 51.79 & 61.87 & 60.04 & 4.31 & 4.84 & 5.28 & 6.45 & 6.28 \\
\hline LSD 5\% & 1.57 & 1.27 & 1.71 & 2.40 & 2.98 & 2.95 & - & 0.17 & - & - & - \\
\hline LSD 1\% & - & 1.74 & - & 3.29 & - & - & - & 0.24 & - & - & - \\
\hline Level of significance & $*$ & $* *$ & $*$ & $* *$ & $*$ & $*$ & $\mathrm{~ns}$ & $* *$ & $\mathrm{~ns}$ & $\mathrm{~ns}$ & $\mathrm{~ns}$ \\
\hline
\end{tabular}

$\mathrm{C}_{\mathrm{t}}=$ Conventional tillage and $\mathrm{Z}_{\mathrm{t}}=$ Zero tillage, $* *$ Significant at $1 \%$ level, $*$ Significant at $5 \%$ level

Table 5. Main effects of tillage on the length and breadth of the longest leaf/plant of garlic

\begin{tabular}{|c|c|c|c|c|c|c|c|c|c|c|}
\hline \multirow[t]{2}{*}{ Treatment } & \multicolumn{5}{|c|}{$\begin{array}{c}\text { Length of the longest leaf }(\mathrm{cm}) \\
\text { at different DAP }\end{array}$} & \multicolumn{5}{|c|}{$\begin{array}{c}\text { Breadth of the longest leaf }(\mathrm{cm}) \\
\text { at different DAP }\end{array}$} \\
\hline & 30 & 50 & 70 & 90 & 110 & 30 & 50 & 70 & 90 & 110 \\
\hline $\mathrm{C}_{\mathrm{t}}$ & 20.31 & 25.16 & 36.68 & 36.80 & 34.55 & 0.47 & 0.77 & 1.17 & 1.29 & 1.24 \\
\hline$Z_{t}$ & 26.83 & 27.47 & 38.69 & 37.32 & 34.07 & 0.56 & 0.82 & 1.22 & 1.30 & 1.26 \\
\hline LSD 5\% & 1.63 & 1.62 & 1.99 & - & - & 0.02 & 0.04 & 0.03 & - & - \\
\hline LSD $1 \%$ & 2.23 & 2.22 & - & - & - & 0.03 & - & - & - & - \\
\hline Level of significance & ** & ** & $*$ & ns & $\mathrm{ns}$ & ** & * & * & ns & ns \\
\hline
\end{tabular}

$\mathrm{C}_{\mathrm{t}}=$ Conventional tillage and $\mathrm{Z}_{\mathrm{t}}=$ Zero tillage

$* *$ Significant at $1 \%$ level, *Significant at $5 \%$ level and ns $=$ Non Significant

Table 6. Main effects of tillage on the yield and yield contributing characteristics of garlic

\begin{tabular}{|c|c|c|c|c|c|c|c|c|c|c|}
\hline \multirow[b]{2}{*}{ Treatment } & \multicolumn{3}{|c|}{ Fresh weight $(\mathrm{g})$ of } & \multicolumn{3}{|c|}{ Dry weight $(\mathrm{g})$ of } & \multirow{2}{*}{$\begin{array}{c}\text { Bulb } \\
\text { diameter } \\
(\mathrm{cm})\end{array}$} & \multirow{2}{*}{$\begin{array}{l}\text { Cloves per } \\
\text { bulb } \\
\text { (no.) }\end{array}$} & \multirow{2}{*}{$\begin{array}{c}\text { Yield } \\
\text { (kg/plot) }\end{array}$} & \multirow{2}{*}{$\begin{array}{l}\text { Yield } \\
\text { (t/ha) }\end{array}$} \\
\hline & \begin{tabular}{|c|} 
Leaves \\
per plant
\end{tabular} & Bulb & $\begin{array}{c}\text { Roots } \\
\text { per plant }\end{array}$ & \begin{tabular}{|c|} 
Leaves \\
per plant
\end{tabular} & Bulb & \begin{tabular}{|c|} 
Roots \\
per plant
\end{tabular} & & & & \\
\hline $\mathrm{C}_{\mathrm{t}}$ & 8.28 & 12.83 & 0.58 & 0.96 & 2.66 & 0.18 & 2.81 & 11.36 & 1.54 & 7.71 \\
\hline $\mathrm{Z}_{\mathrm{t}}$ & 8.29 & 13.24 & 0.61 & 0.99 & 2.72 & 0.19 & 2.85 & 11.56 & 1.56 & 7.80 \\
\hline LSD 5\% & - & - & - & - & - & - & - & - & - & - \\
\hline LSD $1 \%$ & - & - & - & - & - & - & - & - & - & - \\
\hline $\begin{array}{c}\text { Level of } \\
\text { significance }\end{array}$ & ns & ns & ns & ns & ns & ns & $\mathrm{ns}$ & $\mathrm{ns}$ & ns & $\mathrm{ns}$ \\
\hline
\end{tabular}

$\mathrm{C}_{\mathrm{t}}=$ Conventional tillage and $\mathrm{Z}_{\mathrm{t}}=$ Zero tillage, $\mathrm{ns}=$ Non significant

\section{Combined effects of thicknesses of mulches and tillage conditions}

Significant combined effects were found due to the combinations of different thicknesses of mulches and tillage conditions in respect of percent emergence. The maximum emergence $(98.40 \%)$ was obtained from the $6 \mathrm{~cm}$ thick mulch with zero tillage conditions followed in a descending order by $10 \mathrm{~cm}$ thick mulch with zero tillage $(97.37 \%$ ) and $8 \mathrm{~cm}$ thick mulch with zero tillage.

$(96.87 \%)$. The minimum emergence $(89.43 \%)$ was obtained from $12 \mathrm{~cm}$ thick mulch with the conventional tillage (Table 7). The tallest plant
$(70.40 \mathrm{~cm})$ was found from the $10 \mathrm{~cm}$ thick mulch with zero tillage at 90 DAP and the smallest plant $(17.73 \mathrm{~cm})$ was obtained from the plot with the conventional tillage conditions and without mulch at 30 DAP. Again, the maximum number of leaves (6.93) was obtained from $10 \mathrm{~cm}$ thick mulch with zero tillage and the minimum number of leaves per plant (3.40) was obtained from $\mathrm{D}_{0} \mathrm{Z}_{\mathrm{t}}$ (Table 7).

The combined effects of different thicknesses of mulches and the tillage conditions on the length and breadth of the longest leaf per plant were statistically significant. The $10 \mathrm{~cm}$ thick mulch and zero tillage conditions $\left(D_{3} Z_{t}\right)$ produced the longest 
leaf per plant $(45.60 \mathrm{~cm})$ at 70 DAP. On the contrary, at 90 DAP, the maximum breadth of the longest leaf $(1.45 \mathrm{~cm})$ was obtained from $\mathrm{D}_{3} \mathrm{Z}_{\mathrm{t}}$ while the minimum breadth of the longest leaf $(0.39 \mathrm{~cm})$ was recorded from $\mathrm{D}_{0} \mathrm{C}_{\mathrm{t}}$ at 30 days after planting (Table $8)$.

Different treatment combinations of thickness of mulch and tillage conditions exhibited highly significant variations in respect of fresh weight of leaves, bulb and roots per plant. When the plants were grown under zero tillage conditions with $10 \mathrm{~cm}$ mulch, it produced the maximum fresh weight of leaves $(10.33 \mathrm{~g})$ whereas the minimum fresh weight of leaves $(5.53 \mathrm{~g})$ was recorded from the zero tillage conditions without mulch (Table 9). The maximum fresh weight of bulb $(16.20 \mathrm{~g})$ and roots per plant $(0.69 \mathrm{~g})$ were obtained from the $10 \mathrm{~cm}$ thick mulch with zero tillage conditions. The combined effects of different thicknesses of mulches and tillage conditions were found significant for the dry weight of leaves, bulb and roots per plant. The highest dry weight of leaves $(1.16 \mathrm{~g})$, bulb $(3.67 \mathrm{~g})$ and roots
$(0.23 \mathrm{~g})$ per plant were observed at the $10 \mathrm{~cm}$ thick mulch with zero tillage. Significant combined effects of different thicknesses of mulches and tillage conditions were also observed for diameter of bulb that ranged from $2.11 \mathrm{~cm}$ to $3.15 \mathrm{~cm}$. The maximum diameter of bulb $(3.15 \mathrm{~cm})$ was recorded from the $\mathrm{D}_{3} \mathrm{Z}_{\mathrm{t}}(10 \mathrm{~cm}$ thick mulch with zero tillage condition) while the minimum $(2.11 \mathrm{~cm})$ was observed from $\mathrm{D}_{0} \mathrm{Z}_{\mathrm{t}}$ i.e. zero tillage conditions without mulch (Table 9). Conversely, the highest number of cloves per bulb (13.80) was recorded in the treatment combination of $12 \mathrm{~cm}$ thick mulch with zero tillage. The combined effects of different thick mulch and tillage conditions on bulb yield were significant. The maximum (1.99 $\mathrm{kg})$ and the minimum yields of bulb $(0.85 \mathrm{~kg})$ were obtained from the $\mathrm{D}_{3} \mathrm{Z}_{\mathrm{t}}$ and $\mathrm{D}_{0} \mathrm{Z}_{\mathrm{t}}$, respectively. However, significant difference was observed among $\mathrm{D}_{4} \mathrm{Z}_{\mathrm{t}}$ (1.82), $\quad \mathrm{D}_{2} \mathrm{C}_{\mathrm{t}}$ (1.82) and $\mathrm{D}_{2} \mathrm{Z}_{\mathrm{t}}$ (1.81). The treatment combination of $10 \mathrm{~cm}$ thick mulch with zero tillage produced the highest yield ( $9.92 \mathrm{t} / \mathrm{ha}$ ) while the lowest yield (4.23 t/ha) was obtained from no mulch with zero tillage.

Table 7. Combined effects of different thicknesses of water hyacinth mulch and tillage on the growth of garlic

\begin{tabular}{|c|c|c|c|c|c|c|c|c|c|c|c|}
\hline \multirow[t]{2}{*}{ Treatment } & \multirow[t]{2}{*}{$\begin{array}{c}\text { Emergence } \\
(\%)\end{array}$} & \multicolumn{5}{|c|}{$\begin{array}{l}\text { Plant height }(\mathrm{cm}) \\
\text { at different DAP }\end{array}$} & \multicolumn{5}{|c|}{$\begin{array}{c}\text { Number of leaves/plant } \\
\text { at different DAP }\end{array}$} \\
\hline & & 30 & 50 & 70 & 90 & 110 & 30 & 50 & 70 & 90 & 110 \\
\hline $\mathrm{D}_{0} \mathrm{C}_{\mathrm{t}}$ & 91.50 & 17.73 & 26.80 & 37.00 & 53.60 & 45.20 & 3.60 & 4.07 & 4.40 & 6.20 & 5.87 \\
\hline $\mathrm{D}_{0} \mathrm{Z}_{\mathrm{t}}$ & 91.00 & 24.40 & 26.07 & 32.33 & 45.67 & 44.53 & 3.40 & 3.87 & 4.20 & 5.50 & 5.27 \\
\hline $\mathrm{D}_{1} \mathrm{C}_{\mathrm{t}}$ & 95.33 & 23.40 & 31.27 & 47.00 & 60.87 & 58.00 & 4.40 & 4.47 & 5.27 & 6.53 & 6.37 \\
\hline $\mathrm{D}_{1} \mathrm{Z}_{\mathrm{t}}$ & 98.40 & 32.07 & 33.93 & 53.40 & 60.40 & 58.53 & 4.53 & 4.87 & 5.00 & 6.30 & 6.10 \\
\hline $\mathrm{D}_{2} \mathrm{C}_{\mathrm{t}}$ & 94.57 & 27.20 & 34.27 & 54.20 & 63.40 & 59.93 & 4.80 & 4.80 & 5.73 & 6.93 & 6.67 \\
\hline $\mathrm{D}_{2} \mathrm{Z}_{\mathrm{t}}$ & 96.87 & 34.13 & 33.73 & 56.27 & 63.40 & 61.67 & 4.40 & 4.93 & 5.53 & 6.77 & 6.63 \\
\hline $\mathrm{D}_{3} \mathrm{C}_{\mathrm{t}}$ & 93.80 & 27.73 & 32.40 & 45.73 & 59.20 & 57.33 & 4.93 & 4.87 & 5.47 & 6.33 & 6.07 \\
\hline $\mathrm{D}_{3} \mathrm{Z}_{\mathrm{t}}$ & 97.37 & 36.73 & 36.33 & 60.80 & 70.40 & 69.33 & 4.73 & 5.40 & 6.07 & 6.93 & 6.80 \\
\hline $\mathrm{D}_{4} \mathrm{C}_{\mathrm{t}}$ & 89.43 & 25.07 & 30.80 & 45.27 & 57.27 & 57.00 & 4.40 & 4.47 & 5.40 & 6.30 & 6.00 \\
\hline $\mathrm{D}_{4} \mathrm{Z}_{\mathrm{t}}$ & 90.47 & 36.33 & 35.20 & 56.13 & 69.47 & 66.13 & 4.47 & 5.13 & 5.60 & 6.73 & 6.60 \\
\hline LSD 5\% & 3.51 & 2.84 & 3.83 & 5.37 & 6.67 & 6.61 & 0.44 & 0.39 & 0.67 & 0.77 & 0.71 \\
\hline LSD $1 \%$ & 4.81 & 3.90 & 5.24 & 7.36 & 9.13 & - & 0.60 & 0.53 & 0.92 & 1.05 & 0.97 \\
\hline $\begin{array}{c}\text { Level of } \\
\text { significance }\end{array}$ & $* *$ & $* *$ & $* *$ & $* *$ & $* *$ & $*$ & $* *$ & $* *$ & $* *$ & $* *$ & $* *$ \\
\hline
\end{tabular}

** Significant at $1 \%$ level

*Significant at $5 \%$ level

$\mathrm{D}_{0}=$ without mulch, $\mathrm{D}_{1}=6 \mathrm{~cm}, \mathrm{D}_{2}=8 \mathrm{~cm}, \mathrm{D}_{3}=10 \mathrm{~cm}$ and $\mathrm{D}_{4}=12 \mathrm{~cm}$ thick mulch

$\mathrm{C}_{\mathrm{t}}=$ Conventional tillage and $\mathrm{Z}_{\mathrm{t}}=$ Zero tillage

\section{Economic analyses}

The values in the Table 10 indicate that the total cost of production was highest (129416.50Tk. /ha) in $\mathrm{D}_{4} \mathrm{C}_{\mathrm{t}}$ $(12 \mathrm{~cm}$ thick mulch and conventional tillage) and the lowest (93747.50Tk./ha) was from the treatment combination of zero tillage with no mulch $\left(\mathrm{D}_{0} \mathrm{Z}_{\mathrm{t}}\right)$. On the contrary, the highest value of gross return (297600Tk/ha) was obtained from the zero tillage with $10 \mathrm{~cm}$ thick mulch $\left(\mathrm{D}_{3} \mathrm{Z}_{\mathrm{t}}\right)$ and the lowest value of gross return (126900Tk. /ha) was obtained from the $\mathrm{D}_{0} \mathrm{Z}_{\mathrm{t}}$ (Zero tillage with no mulch). Simultaneously, the lowest net returns $(33152.50 \mathrm{Tk}$. /ha) was received from the same treatment combination. In case of benefit-cost ratio, the highest value (2.89) was recorded from the zero tillage with $10 \mathrm{~cm}$ thick mulch and the lower of 1.35 was also in the combination of zero tillage with no mulch. 
Table 8. Combined effects of different thicknesses of water hyacinth mulch and tillage on length and breadth of the longest leaf/plant of garlic

\begin{tabular}{|c|c|c|c|c|c|c|c|c|c|c|}
\hline \multirow[t]{2}{*}{ Treatment } & \multicolumn{5}{|c|}{$\begin{array}{c}\text { Length of the longest leaf }(\mathrm{cm}) \text { at } \\
\text { different DAP }\end{array}$} & \multicolumn{5}{|c|}{$\begin{array}{c}\text { Breadth of the longest leaf }(\mathrm{cm}) \text { at } \\
\text { different DAP }\end{array}$} \\
\hline & 30 & 50 & 70 & 90 & 110 & 30 & 50 & 70 & 90 & 110 \\
\hline $\mathrm{D}_{0} \mathrm{C}_{\mathrm{t}}$ & 15.93 & 21.33 & 31.40 & 31.33 & 28.67 & 0.39 & 0.65 & 1.06 & 1.14 & 1.09 \\
\hline $\mathrm{D}_{0} \mathrm{Z}_{\mathrm{t}}$ & 19.47 & 21.53 & 24.53 & 29.40 & 24.67 & 0.47 & 0.72 & 1.00 & 1.07 & 1.05 \\
\hline $\mathrm{D}_{1} \mathrm{C}_{\mathrm{t}}$ & 18.87 & 25.60 & 36.00 & 36.80 & 36.07 & 0.46 & 0.79 & 1.15 & 1.27 & 1.24 \\
\hline $\mathrm{D}_{1} \mathrm{Z}_{\mathrm{t}}$ & 25.33 & 26.87 & 39.20 & 35.33 & 33.60 & 0.55 & 0.78 & 1.22 & 1.29 & 1.25 \\
\hline $\mathrm{D}_{2} \mathrm{C}_{\mathrm{t}}$ & 22.73 & 27.27 & 42.87 & 39.80 & 38.33 & 0.51 & 0.83 & 1.25 & 1.39 & 1.35 \\
\hline $\mathrm{D}_{2} \mathrm{Z}_{\mathrm{t}}$ & 28.40 & 29.13 & 43.00 & 38.13 & 35.93 & 0.57 & 0.85 & 1.27 & 1.35 & 1.31 \\
\hline $\mathrm{D}_{3} \mathrm{C}_{\mathrm{t}}$ & 23.67 & 26.33 & 37.87 & 39.20 & 35.47 & 0.52 & 0.79 & 1.23 & 1.35 & 1.27 \\
\hline $\mathrm{D}_{3} \mathrm{Z}_{\mathrm{t}}$ & 30.87 & 30.27 & 45.60 & 42.80 & 39.40 & 0.61 & 0.91 & 1.34 & 1.45 & 1.42 \\
\hline $\mathrm{D}_{4} \mathrm{Ct}$ & 20.33 & 25.27 & 35.27 & 36.87 & 34.20 & 0.47 & 0.80 & 1.17 & 1.27 & 1.26 \\
\hline $\mathrm{D}_{4} \mathrm{Z}_{\mathrm{t}}$ & 30.07 & 29.53 & 41.13 & 40.93 & 36.73 & 0.59 & 0.87 & 1.23 & 1.35 & 1.29 \\
\hline LSD 5\% & 3.64 & 3.62 & 4.44 & 3.91 & 2.85 & 0.05 & 0.09 & 0.08 & 0.20 & 0.07 \\
\hline LSD 1\% & 4.98 & 4.97 & 6.09 & 5.36 & 3.91 & 0.07 & 0.13 & - & 0.28 & - \\
\hline $\begin{array}{c}\text { Level of } \\
\text { significance }\end{array}$ & $* *$ & $* *$ & $* *$ & $* *$ & $* *$ & $* *$ & $* *$ & $*$ & $*$ & $*$ \\
\hline
\end{tabular}

** Significant at $1 \%$ level, *Significant at $5 \%$ level

$\mathrm{D}_{0}=$ without mulch, $\mathrm{D}_{1}=6 \mathrm{~cm}, \mathrm{D}_{2}=8 \mathrm{~cm}, \mathrm{D}_{3}=10 \mathrm{~cm}$ and $\mathrm{D}_{4}=12 \mathrm{~cm}$ thick mulch

$\mathrm{C}_{\mathrm{t}}=$ Conventional tillage, $\mathrm{Z}_{\mathrm{t}}=$ Zero tillage

Table 9. Combined effect of different thicknesses of water hyacinth mulch and tillage on the yield and yield contributing characteristics of garlic

\begin{tabular}{|c|c|c|c|c|c|c|c|c|c|}
\hline \multirow[b]{2}{*}{ Treatment } & \multicolumn{3}{|c|}{ Fresh weight (g) of } & \multicolumn{3}{|c|}{ Dry weight (g) of } & \multirow{2}{*}{$\begin{array}{c}\text { Bulb } \\
\text { diameter } \\
(\mathrm{cm})\end{array}$} & \multirow{2}{*}{$\begin{array}{c}\text { Cloves } \\
\text { per bulb } \\
\text { (no.) }\end{array}$} & \multirow{2}{*}{$\begin{array}{c}\text { Yield } \\
\text { per plot } \\
(\mathrm{kg})\end{array}$} \\
\hline & $\begin{array}{c}\text { Leaves } \\
\text { per plant }\end{array}$ & Bulb & $\begin{array}{c}\text { Roots } \\
\text { per plant }\end{array}$ & $\begin{array}{c}\text { Leaves } \\
\text { per plant }\end{array}$ & Bulb & $\begin{array}{c}\text { Roots } \\
\text { per plant }\end{array}$ & & & \\
\hline $\mathrm{D}_{0} \mathrm{C}_{\mathrm{t}}$ & 6.00 & 10.13 & 0.51 & 0.81 & 1.63 & 0.15 & 2.37 & 8.20 & 1.23 \\
\hline $\mathrm{D}_{0} \mathrm{Z}_{\mathrm{t}}$ & 5.53 & 7.93 & 0.47 & 0.65 & 1.27 & 0.09 & 2.11 & 7.33 & 0.85 \\
\hline $\mathrm{D}_{1} \mathrm{C}_{\mathrm{t}}$ & 8.13 & 12.53 & 0.56 & 0.95 & 2.91 & 0.18 & 2.89 & 11.20 & 1.56 \\
\hline $\mathrm{D}_{1} \mathrm{Z}_{\mathrm{t}}$ & 7.27 & 11.80 & 0.58 & 0.95 & 2.07 & 0.18 & 2.81 & 10.27 & 1.34 \\
\hline $\mathrm{D}_{2} \mathrm{C}_{\mathrm{t}}$ & 9.80 & 15.40 & 0.62 & 1.10 & 3.13 & 0.21 & 3.07 & 12.47 & 1.82 \\
\hline $\mathrm{D}_{2} \mathrm{Z}_{\mathrm{t}}$ & 9.20 & 14.53 & 0.65 & 1.09 & 3.22 & 0.22 & 3.07 & 13.60 & 1.81 \\
\hline $\mathrm{D}_{3} \mathrm{C}_{\mathrm{t}}$ & 9.20 & 14.00 & 0.60 & 1.00 & 3.04 & 0.19 & 2.99 & 13.47 & 1.68 \\
\hline $\mathrm{D}_{3} \mathrm{Z}_{\mathrm{t}}$ & 10.33 & 16.20 & 0.69 & 1.16 & 3.67 & 0.23 & 3.15 & 12.80 & 1.99 \\
\hline $\mathrm{D}_{4} \mathrm{C}_{\mathrm{t}}$ & 8.27 & 12.07 & 0.59 & 0.95 & 2.59 & 0.19 & 2.73 & 11.47 & 1.41 \\
\hline $\mathrm{D}_{4} \mathrm{Z}_{\mathrm{t}}$ & 9.13 & 15.73 & 0.65 & 1.07 & 3.35 & 0.21 & 3.10 & 13.80 & 1.82 \\
\hline LSD $5 \%$ & 1.61 & 2.31 & 0.12 & 0.16 & 0.30 & 0.03 & 0.24 & 2.44 & 0.23 \\
\hline LSD $1 \%$ & 2.21 & 3.16 & 0.17 & 0.22 & 0.41 & 0.05 & - & 3.34 & 0.32 \\
\hline $\begin{array}{c}\text { Level of } \\
\text { significance }\end{array}$ & $* *$ & $* *$ & $* *$ & $* *$ & $* *$ & $* *$ & $*$ & $* *$ & $* *$ \\
\hline
\end{tabular}

** Significant at $1 \%$ level, * Significant at $5 \%$ level

$\mathrm{C}_{\mathrm{t}}=$ Conventional tillage and $\mathrm{Z}_{\mathrm{t}}=$ Zero tillage

$\mathrm{D}_{0}=$ without mulch, $\mathrm{D}_{1}=6 \mathrm{~cm}, \mathrm{D}_{2}=8 \mathrm{~cm}, \mathrm{D}_{3}=10 \mathrm{~cm}$ and $\mathrm{D}_{4}=12 \mathrm{~cm}$ thick mulch 
Table 10. Cost and return analyses of garlic due to different thicknesses of mulch and tillage

\begin{tabular}{|c|c|c|c|c|c|}
\hline $\begin{array}{c}\text { Treatment } \\
\text { combinations }\end{array}$ & $\begin{array}{c}\text { Yield } \\
(\mathrm{t} / \mathrm{ha})\end{array}$ & $\begin{array}{c}\text { * Gross return } \\
\text { (Tk. / ha }\end{array}$ & $\begin{array}{c}\text { Total cost of production } \\
\text { (Tk.) }\end{array}$ & $\begin{array}{c}\text { Net return } \\
(\text { Tk.) }\end{array}$ & BCR \\
\hline $\mathrm{D}_{0} \mathrm{C}_{\mathrm{t}}$ & 6.17 & 185100 & 117597.50 & 67502.50 & 1.57 \\
\hline $\mathrm{D}_{0} \mathrm{Z}_{\mathrm{t}}$ & 4.23 & 126900 & 93747.50 & 33152.50 & 1.35 \\
\hline $\mathrm{D}_{1} \mathrm{C}_{\mathrm{t}}$ & 7.82 & 234600 & 121388.50 & 113211.50 & 1.93 \\
\hline $\mathrm{D}_{1} \mathrm{Z}_{\mathrm{t}}$ & 6.68 & 200400 & 97538.50 & 102861.50 & 2.05 \\
\hline $\mathrm{D}_{2} \mathrm{C}_{\mathrm{t}}$ & 9.08 & 272400 & 124064.50 & 148335.50 & 2.20 \\
\hline $\mathrm{D}_{2} \mathrm{Z}_{\mathrm{t}}$ & 9.07 & 272100 & 100214.50 & 171885.50 & 2.72 \\
\hline $\mathrm{D}_{3} \mathrm{C}_{\mathrm{t}}$ & 8.42 & 252600 & 126740.50 & 125859.50 & 1.99 \\
\hline $\mathrm{D}_{3} \mathrm{Z}_{\mathrm{t}}$ & 9.92 & 297600 & 102890.50 & 194709.50 & 2.89 \\
\hline $\mathrm{D}_{4} \mathrm{C}_{\mathrm{t}}$ & 7.07 & 212100 & 129416.50 & 82683.50 & 1.64 \\
\hline $\mathrm{D}_{4} \mathrm{Z}_{\mathrm{t}}$ & 9.12 & 273600 & 105566.50 & 168033.50 & 2.59 \\
\hline
\end{tabular}

$\mathrm{C}_{\mathrm{t}}=$ Conventional tillage and $\mathrm{Z}_{\mathrm{t}}=$ Zero tillage

$\mathrm{D}_{0}=$ without mulch, $\mathrm{D}_{1}=6 \mathrm{~cm}, \mathrm{D}_{2}=8 \mathrm{~cm}, \mathrm{D}_{3}=10 \mathrm{~cm}$ and $\mathrm{D}_{4}=12 \mathrm{~cm}$ thick mulch

*Rate of fresh garlic @30Tk./kg

\section{Discussion and Conclusion}

Initial soil moisture content was higher in zero tillage conditions $(71.42 \%)$ than the conventional tillage $(30.26 \%)$ before the planting of garlic. Furthermore, zero tillage conserved more moisture than the dry land conditions $(40.23-58.67 \%$ in zero tillage and $19.63-23.86 \%$ in conventional one after 15 days after planting). As a result, moisture was available at the root zone of the plant enhancing vegetative growth and ultimately higher yield in the combination of zero tillage with $10 \mathrm{~cm}$ thick mulch. No-tillage favoured greater and deeper water conservation in the soil profile and finally profuse root growth. Furthermore, mulching conserved soil moisture, regulated soil temperature and suppressed weed growth. The field where appropriate amount of mulch was not applied, crop did not perform well in respect of vegetative growth as well as yield. Prihar and Jalota (1988) opined that shallow tillage was more effective in water conservation for fine textured soil than for coarse textured soil. The results of the present study are in partial agreement with those of Aliuddin (1986), Verma et al. (1991), Khuhro et al. (2002) and Mondal et al. (2007). Goncharov (2007) concluded that mulching with a $10-12 \mathrm{~cm}$ layer of cereal straw improved garlic height, leaf length and extended the growing period by 5-6 days. From the results it could be concluded that $10 \mathrm{~cm}$ thick mulch with zero tillage produced the maximum yield of garlic than the control. Therefore, garlic cultivation under zero tillage with proper amount of mulch was a very profitable production system.

\section{References}

Augusti, K. T. 1977. Hypocholesterolaemic effect of garlic (Allium sativum L), Indian J. Expt. Biol., 15(6):489-490.

Bose, T. K. and Som, M. G. 1990. Vegetable Crops in India (1st edn.), Naya Prakash, Calcutta, India, pp. 583-601.

Gomez, K. A. and Gomez, A. A. 1984. Statistical Procedure for Agricultural Research. John Wiely and Sons. Inc. New York, pp. 67-215.

Goncharov, A. N. 2007. Effect of soil mulching on the growth, development and yield of winter garlic. Conference on "Basic trends in scientific and technological progress in vegetable production in countries of the CIS and the Baltic" held in Minsk, Belarus, in 2006, Kartofel'i. Ovoshchi, 7: 32.

Khuhro, G. A.; Tunio, G. S.; Nizamuddin, M. and Nihaluddin, M. 2002. Zero tillage sowing method of wheat followed by transplanted rice (in rice-wheat system). Pakistan Journal of Applied Science, 2(3): 307.

Mondal, N. A.; Hossain, S. M. A.; Bhuiya S. U. and Jahiruddin, M. 2007. Tillage and mulch effects on soil environment, growth and yield of rainfed barley. Annals of Bangladesh Agriculture, 11(2):33-44. 
Prihar, S. S. and Jalota, S. K. 1988. Role of shallow tillage in soil water management. In: Proceedings of International Conference of Dry land Farming: A Global Perspective edited by Unger P. W.; Sneed T. V.; Jorden W. R. and Jensen R. L.: Texas Agricultural Experiment Station, pp. 128-130.

Pruthi, J. S. 2006. Spices and Condiments. National Book Trust of India, New Delhi, 322 p.

Verma, U. N.; Sinha, M. K. and Srivastava, V. C. 1991. Effect of tillage and nitrogen management on wheat (Triticum aestivum) after transplanted rice (Oryza sativa). Indian Journal of Agricultural Science, 61 (11): 795-802.

Baten, M. A.; Nahar, B. S.; Sarkr, S. C. and Khan, M.A. H. 1995. Effect of Different Mulches on the Growth and Yield of Late Planted Garlic (Allium jastivus L) . Pak. J. Ind. Res., 38 (3-4): 140-141.

Baten, M. A.; Nahar, B. S.; Sarkr, S. C. and Muhsi, A. A. A. 1992. Effect of Different Intervals of Irrrigation on Growth and Yield of Garlic. Pak. J. Sci. Ind. Res., 35 (7-8): 297-299. 